Maria Rudnicka

[Wrocław ]

\title{
Czy istnieje życiorys mówiony? \\ O przenikaniu gatunków mówionych i pisanych \\ - próba genologii na przykładzie analizy wypowiedzi autobiograficznych
}

Wrocławski Rocznik

Historii Mówionej

Rocznik VII, 2017

ISSN 2084-0578

DOI: 10.26774 /wrhm.167

\section{Wprowadzenie}

W artykule zostanie opisane zjawisko genologiczne, które można obserwować w obszarze historii mówionej: relacje biograficzno-narracyjne rozpoczęte przez prowadzącego wywiad prośbą opowiedzenia o swoim życiu przez Świadka Historii ${ }^{1}$ zaczynają się zgodnie ze znanym z pragmatyki urzędowej schematem. Ponieważ swobodne wypowiedzi autobiograficzne (stanowiące fragmenty większych całości) są do siebie podobne pod względem struktury, a czytanie ich przypomina czytanie życiorysu, zastanowię się, czy istnieje gatunek, który można nazwać życiorysem mówionym. Analiza została przeprowadzona na materiale dostępnym w Archiwum Historii Mówionej Ośrodka „Pamięć i Przyszłość” we Wrocławiu.

Zdecydowałam się na pisownię Świadek Historii wielką literą bez cudzysłowu - w dokumentach Ośrodka pisownia jest niejednorodna („Świadek Historii” lub Świadek Historii), w tekście zamiennie będę stosować pojęcie Świadek Historii i Świadek. 
W pierwszej części artykułu opiszę gatunek jako wzorzec tekstowy, potem przedstawię rodzaje gatunków i ich podział na pierwotne i wtórne oraz zarysuję różnicę między językiem pisanym a mówionym. W następnej części przyjrzę się życiorysowi: jego budowie i cechom języka, a w ostatniej, w kontekście przedstawionych informacji, postaram się przeanalizować pierwsze części relacji Świadków Historii i odpowiedzieć na pytanie o istnienie życiorysu mówionego jako gatunku.

\section{Gatunek jako wzorzec tekstów}

Zdaniem Michaiła Bachtina mówimy wyłącznie gatunkami ${ }^{2}$ - nie ma wypowiedzi, która nie realizowałaby określonego wzorca gatunkowego. Nie zawsze jesteśmy tego w pełni świadomi, ale umiejętność tworzenia konkretnych, ukształtowanych gatunkowo tekstów przyjęliśmy wraz z uczeniem się języka. Umieć mówić, to umieć posługiwać się gatunkami. Zdolność tworzenia gatunków jest równoznaczna z kompetencjami językowymi i dana całym społecznościom³ Jakim więc gatunkiem posługują się Świadkowie Historii, skoro prawdopodobieństwo zainspirowania się cudzą opowieścią autobiograficzną przed skonstruowaniem własnej relacji biograficznej w sytuacji rozmowy z badaczem jest bardzo niewielkie? Relacje Świadków Historii nie są publikowane masowo - są dostępne w siedzibach instytucji kultury (głównie: muzeów) czy ośrodków badawczych, zajmujących się tą problematyką (których jest w Polsce niewiele), lub w Internecie. Świadkowie - jako starsi ludzie - mają utrudniony dostęp do tego medium. Taką wypowiedź - rozumianą jako pełną i zamkniętą opowieść o własnym życiu - w konkretnej sytuacji (instytucjonalnej) konstruują często pierwszy i jedyny raz w życiu, gdyż nawet jeśli w przeszłości w rodzinie opowiadano historie rodzinne, były to wybrane anegdoty ${ }^{4}$ lub krótkie epizody z życia.

$2 \quad$ M. Bachtin, Problem gatunków mowy, [w:] idem, Estetyka twórczości słownej, Warszawa 1986, s. 348. To jego koncepcja, obok koncepcji L. Wittgensteina (koncepcja podobieństwa rodzinnego) i teorii prototypów (E. Roch), w znaczącym stopniu wpłynęła na dzisiejsze rozumienie gatunku, por. D. Ostaszewska, Genologia lingwistyczna jako subdyscyplina współczesnego językoznawstwa, [w:] Polska genologia lingwistyczna, red. D. Ostaszewska, R. Cudak, Warszawa 20o8, s. 19-21.

$3 \quad$ M. Bachtin, op. cit., s. 383 .

${ }_{4} \quad$ O gawędzie autobiograficznej pisze Roman Loth w artykule Franciszka Fiszera anegdoty autobiograficzne w zbiorze Żywiot stowa. Literatura i jej formy mówione, red. J. Maciejewski, Łódź 2007. 
Czym jest gatunek mowy? Zdaniem Bachtina to wzorzec organizacji

tekstu ukształtowany historycznie i kulturowo ${ }^{5}$. Pojedynczy, konkretny, trwały pod względem tematycznym i stylistycznym typ wypowiedzi osób uczestniczących w określonej strefie działalności, posiadający stałą, identyfikowaną intuicyjnie lub rozpoznawalną strukturę ${ }^{6}$. Gatunek stanowi określoną całość i jako taka jednocześnie ukrywa w sobie pewne kategorie formalnojęzykowe, kognitywne i pragmatyczne. Poszczególne wypowiedzi aktualizują ten dany kulturowo i historycznie wzorzec?

Podobnego zdania jak Bachtin jest Stefania Skwarczyńska, która niemal równolegle z nim (ale niezależnie od niego), była prekursorką teorii gatunku. Jej zdaniem nie istnieje taki twór językowy, który byłby pozbawiony charakteru rodzajowego; rodzajowość jest naturalna i konieczna dla każdego tekstu. Oczywiście konkretny utwór może być zbudowany na podstawie więcej niż jednej formy rodzajowej ${ }^{8}$.

Można powiedzieć, że wzorzec gatunkowy odgrywa rolę podobną jak zasady gramatyki. Zasady mówią, jak łączyć poszczególne słowa w zdania lub jak budować nowe słowa, wzorzec gatunkowy - jak konstruować wypowiedzi.

Z terminem „gatunek” wiążą się dwa pojęcia: „sytuacja komunikacyjna” i „kontekst” (konsytuacja, rama sytuacyjna wypowiedzi itp.). W węższym znaczeniu sytuacja komunikacyjna to kategoria zewnątrztekstowa odnosząca się do tego, co, oprócz języka wpływa na przestrzeń, w której są rozmówcy; w szerszym - to wszystkie okoliczności pozwalające skutecznie zrealizować wszystkie cele komunikacyjne: wartości społeczne, wiedza uczestników, oceny, kompetencje kulturowe'. Z kolei „kontekst” odnosi się do tekstu: do gramatycznych i wewnątrztekstowych zabiegów związanych ze spójnością tekstów ${ }^{10}$.

$5 \quad$ S. Gajda, Gatunkowe wzorce wypowiedzi, [w:] Polska genologia..., s. 130.

$6 \quad$ M. Bachtin, op. cit., s. 351.

7 A wszelkie zmiany zachodzące we wzorcu (wprowadzane do wzorca) są innowacjami i mogą go zmienić, M. Bachtin, op. cit., s. 131.

$8 \quad$ S. Skwarczyńska, Wstęp do nauki o literaturze, t. 3, Warszawa 1965, s. 72.

9 D. Ostaszewska, Genologia lingwistyczna..., s. 32.

$10 \quad$ Ibidem, s. 32-33. 
Początkowo istniały tylko gatunki mówione. Wynalezienie pisma pomogło w utrwalaniu słowa mówionego, a z czasem zaowocowało ukształtowaniem się dwóch odmian języka: pisanej i mówionej.

W języku pisanym zdania są najczęściej dwuczłonowe: składają się z podmiotu i orzeczenia, istnieją także mniej lub bardziej rozbudowane grupy ich obu. W języku mówionym natomiast nie zawsze tak jest; częściej występują zdania eliptyczne, niepełne. Rzadziej pojawia się składnia, którą trzeba wcześniej zaplanować, np. struktury imiesłowowe. Dla języka mówionego charakterystyczne jest także wyraźniejsze niż w przypadku języka pisanego zabarwienie emocjonalne i środowiskowe (np. regionalizmy) ${ }^{11}$. Poza tym wypowiedź w języku mówionym może być uzupełniana przez gestykulację czy intonację głosu, a wszelkie niejasności można wyjaśniać na bieżąco, to, co napisane, nie może być uzupełniane - to całość dana jednorazowo $^{12}$. W konsekwencji rozwoju różnych typów języka powstały także gatunki typowe dla każdego $\mathrm{z}$ nich ${ }^{13}$ : mówione i pisane. Jak zostało powiedziane, każda aktywność językowa jest aktywnością gatunkową, gatunki są obecne we wszystkich odmianach i stylach językowych w całym uniwersum mowy, nie tylko w literaturze.

Gatunki dzieli się na prymarne i pochodne (wtórne, sekundarne). Pierwsze rodzą się w naturalnych sytuacjach społeczno-komunikacyjnych,

11 D. Buttler, H. Kurkowska, H. Satkiewicz, Kultura języka polskiego, t. 1, Warszawa 1971, s. 51-53.

12 Oczywiście pojawia się pytanie, co z tekstem pisanym w komputerowych edytorach tekstowych, które mogą być nieustannie uzupełniane: czy to nie ma wpływu na charakter tekstu pisanego. Powyższe stwierdzenia: o niemożności uzupełnienia tekstu odnoszą się do wypowiedzi uznanej za zamkniętą, czyli kiedy jest odbierana przez adresata (list po wysłaniu, tekst po wydruku, książka, która trafiła do księgarń) - wtedy nie może być uzupełniona, zostaje tylko to, co na papierze. Warto dodać, że w ostatnim czasie podział języka na mówiony i pisany przestaje być tak klarowny i prosty ze względu na rozwój technologii komputerowych i teleinformatycznych. Szczególnie te drugie spowodowały, że język pisany może być wykorzystywany w komunikacji jednoczesnej podmiotów komunikowania się (do tej pory było to zastrzeżone dla komunikacji bezpośredniej, ustnej), przysłużyło się temu istnienie komunikatorów internetowych do rozmawiania on-line, typu Messenger, Gadu-Gadu, czaty internetowe.

13 J. Maciejewski, Literatura i jej formy mówione, [w:] Żywioł..., s. 12. 
wtórne powstają w wyniku wielu przekształceń ${ }^{14}$, przede wszystkim z prze-

niesienia gatunku z pierwotnego kontekstu komunikacyjnego $\mathrm{w}$ inny ${ }^{15}$. Przykładem może być pojawianie się w wypowiedziach potocznych ludzi niewykształconych form przeniesionych z języka urzędowego. Nie ograniczają się one do zapożyczeń leksykalnych czy frazeologicznych - przenikają całe konstrukcje i powodują przesunięcia w obrębie cech pragmatycznych wypowiedzi ${ }^{16}$. Zwykle gatunki pisane są wtórne wobec mówionych.

Te ostatnie dzieli się ${ }^{17}$ na gatunki mowy: naturalnej (potocznej), starannej (tworzącej kod rozwinięty ${ }^{18}$ ) oraz oficjalnej publicznej. Dorota Rancew-Sikora mówi o: rozmowie, pogawędce, kłótni, rozmowie formalnej (wśród których wymienia rozmowę kwalifikacyjną, zebrania i przedzebrania, przemówienia publiczne), wywiadzie (dziennikarskim, medycznym, prawnym, prowadzonym przez instytucje powołane do udzielania pomocy) ${ }^{19}$. Nie ma wśród nich mowy o życiorysie mówionym ani o innej formie wypowiedzi podobnej $\mathrm{mu}^{20}$, żadna też $\mathrm{z}$ form opisanych przez badaczkę nie realizuje cech obserwowanych w wypowiedzi Świadka Historii. Ze względu na to, że genologia jest nauką, która narodziła się w XX w., warto nadmienić

14 M. Zaśko-Zielińska, Przez okno świadomości. Gatunki mowy w świadomości użytkowników języka, Wrocław 2002, s. 18.

15 T. Dobrzyńska, Badanie struktury tekstu, [w:] Polska genologia..., s. 91.

16 Ibidem.

17 Ponieważ wypowiedź Świadka Historii to wypowiedź mówiona, celowo pominięto tutaj kategoryzację gatunków pisanych.

18 Kod ograniczony to typ języka, który ma stosunkowo ubogi repertuar gatunków wypowiedzi i odmian stylowych, występuje w nim dużo zaimków, partykuł, operatorów nawiązań (typu: no i); notuje się wysoką frekwencję emocjonalnych środków wyrazu (nierzadko prymitywnych) i znaczną liczbę błędów językowych. Opozycją wobec niego jest kod rozwinięty - bardziej zróżnicowany pod względem stylistyczno-językowym; wykorzystuje on nazwy semantycznie pełne, jest wysublimowany w sferze ekspresji wypowiedzi, respektuje normy językowe i uzus; por.: A. Wilkoń, Gatunki mówione, Internetowa Konferencja Naukowa „Porozmawiajmy o rozmowie”, http:// uranos.cto.us.edu.pl/ rozmowa/wilkon.htm (dostęp: 25 VII 2016 r.).

19 Por. D. Rancew-Sikora, Analiza konwersacyjna jako metoda badania rozmów codziennych, Warszawa 2007, s. 91-143.

20 Gatunki mowy naturalnej to: rozmowa, opowiadanie, kłótnia, plotka, dowcip (kawał), lament. Gatunki mowy starannej to: dyskusja, flirt, konwersacja, anegdota (dykteryjka), maksyma, wywiad. Gatunki mowy oficjalnej publicznej: dyskusja panelowa, przemówienie, konferencja, komentarz (np. do ważnych wydarzeń), negocjacje, mowa obrończa, zob. ibidem. 
za Aleksandrą Okopień-Sławińską, że to, co do tej pory wiadomo o gatunkach mowy, jest intuicyjne i przybliżone ${ }^{21}$. Niektóre z nich są wyraźnie skonwencjonalizowane, inne mają tylko nazwę i szkicowy opis. Tylko część z nich została naukowo opisana i nazwana.

\section{Życiorys jako gatunek mowy}

Samo mówienie o sobie, rozumiane jako refleksja autobiograficzna, opowiadanie historii swojego życia, nie jest niczym nowym: ludzie o sobie mówili zawsze, od czasów starożytnych znane było zapisywanie swojego życia, a od XVIII w. popularne stało się prowadzenie pamiętników i dokumentów osobistych. Od kilkunastu lat uczenie się przez opowiadanie o sobie jest ważnym obszarem edukacji dorosłych ${ }^{22}$. Warto podkreślić jednak, że wyjątkowe jest samo mówienie o sobie w sposób całościowy: na co dzień, nawet jeśli to robimy, nie opowiadamy o swoim życiu od dnia narodzin.

Analizując wstępy do wypowiedzi historii mówionej, należy zastanowić się, do jakiego gatunku można przypisać taką wypowiedź - akt mowy zachodzący w określonej sytuacji. O jej treści decyduje mówiący (ingerencja prowadzącego wywiad, czy - bardziej trafnie chyba - słuchacza, eksploratora, jest ograniczona - nie narzuca on tematu). Początek stanowi prośba o opowieść o swoim życiu, która kończy się w chwili, o której zdecyduje opowiadający. Na pewno jest to monolog; słuchacz ma za zadanie słuchać, wszelkie pytania, które mogą pojawić się w czasie wypowiedzi, może zadać dopiero po skończeniu opowieści Świadka Historii. Niecodzienna jest sytuacja

21 A. Okopień-Sławińska, Teoria wypowiedzi jako podstawa komunikacyjnej teorii dzieta literackiego, „Pamiętnik Literacki”, nr 79/1 (1988), s. 179-180.

22 Por. liczne publikacje polskich i zagranicznych andragogów, m.in.: O. Czerniawska, Drogi $i$ bezdroża andragogiki i gerontologii. Szkice i rozprawy, Łódź 2007; eadem, Szkice $z$ andragogiki $i$ gerontologii, Łódź 2007; eadem, Rola marzeń $w$ życiu ludzi starszych, „Rocznik Andragogiczny”, (2010), s. 107-113; Uczenie się z (wtasnej) biografii, red. E. Dubas, W. Świtalski, Łódź 2011; Biografie edukacyjne. Wybrane konteksty, red. E. Dubas, J. Stelmaszczyk, Łódź 2014; Biografie i uczenie się, red. E. Dubas, J. Stelmaszczyk, Łódź 2015; P. Alheit, Teoria biografii jako fundament pojęciowy uczenia się przez całe życie, „Teraźniejszość - Człowiek - Edukacja”, t. 18 (2015), nr 4(72); A. Bron, Biograficzność w badaniach andragogicznych, „Dyskursy Młodych Andragogów" (2009); D. Demetrio, Autobiografia. Terapeutyczny wymiar pisania o sobie, Kraków 20oo; idem, Pedagogika pamięci. W trosce o nas samych, z myślq o innych, Łódź 2009; P. Dominicé, Uczyć się z życia. Biografia edukacyjna $w$ edukacji dorostych, Łódź 2006. 
komunikacyjna: wywiad przeprowadza się w obecności przedstawiciela instytucji, która zbiera wywiady w celach badawczych. Jasno określony cel to opowiedzenie historii swojego życia przez Świadka. Wypowiedzi te są do siebie podobne: w zakresie treści, języka, formy i przypominają powszechnie znany wzorzec życiorysu - gatunku pisanego.

Choć sam termin „życiorys” jest dość obszerny (Stownik Języka Polskiego podaje, że jest to „opis czyjegoś życia i czyjejś działalności”23), w artykule stosuję go z myślą o dokumencie urzędowym, który w XX w. przedkładano $^{24}$, gdy starano się o przyjęcie do szkoły (szkoła średnia, studia) lub do pracy. To gatunek pisany, przynależny do języka urzędowego ${ }^{25}$; rodzaj skonwencjonalizowanej wypowiedzi biograficznej o charakterze informacyjnym, zawierający opis działalności zawodowej i wybranych aspektów własnego życia, takich jak dom rodzinny, otrzymane wykształcenie, zainteresowania ${ }^{26}$. Aby być precyzyjną, pisząc o autobiograficznym dokumencie pisanym, będę stosować pojęcie „życiorys” lub „życiorys pisany” dla odróżnienia od wypowiedzi mówionej Świadków Historii mającej znamiona życiorysu: na potrzeby tego tekstu będę stosować termin „życiorys mówiony”.

Życiorys to gatunek, którym posługiwano się jeszcze w latach 9o. XX w. Stopniowo, w związku z przemianami na rynku pracy, był wypierany przez curriculum vitae $(\mathrm{CV})^{27}$ - dokument, w którym podaje się tylko informacje dotyczące edukacji i doświadczenia zawodowego kandydatów na pracowników; struktura tekstu nie przewiduje miejsca na dzielenie się informacjami dotyczącymi życia osobistego czy rodzinnego.

Aby zbadać, czy wypowiedź Świadka Historii jest gatunkowo podobna do życiorysu, konieczne jest prześledzenie struktury tego rodzaju tekstu.

23 Życiorys, [w:] Stownik Języka Polskiego PWN, http://sjp.pwn.pl/sjp/zyciorys;2548402. html (dostęp: 25 VII 2016 r.).

24 Trudno jednoznacznie określić, kiedy życiorys w znanej dziś formie zaczął funkcjonować w polskiej praktyce urzędowej, z pewnością, w związku z zaborami i nieistnieniem urzędowej odmiany polszczyzny wtedy, mogło to nastąpić dopiero w XX w. Od końca lat 9o. XX w. zaczął być wypierany przez CV.

25 Tzn. wykorzystywany w sytuacjach oficjalnego kontaktu człowieka z instytucją.

26 H. Belke, Problemy typologii i klasyfikacji tekstów użytkowych, „Pamiętnik Literacki”, nr 70 (1979), z. 3, s. 323-346.

27 CV to także opis życia, ale różnica tkwi w sposobie notacji: tu zapis ankietowy ujmuje wydarzenia związane z edukacją, doświadczenie zawodowe, ukończone kursy, wymienia się w nim także obszary zainteresowań czy sposoby spędzania wolnego czasu, nie jest jednak zachowana spójność narracyjna. 
Zbadały ją Boniecka i Panasiuk ${ }^{28}$, ustalając, że stałymi jego elementami są:

I. Dane personalne (imię i nazwisko, data i miejsce urodzenia, pochodzenie społeczne, adres zamieszkania);

II. Opis przebiegu edukacji (szkoła podstawowa, szkoła średnia/zawodowa, studia);

III. Informacje o kwalifikacjach;

IV. Etapy pracy zawodowe;

V. Informacje o rodzinie;

VI. Przynależność do organizacji społecznych;

VII. Zainteresowania;

VIII. Perspektywy na przyszłość ${ }^{29}$.

W dokumencie tym mówiono o pochodzeniu społecznym i przynależności zawodowej; niekiedy (choć dość rzadko) podawano szczegóły dotyczące wielkości rodziny, z której się pochodziło, wieku jej członków czy wykonywanych przez nich zajęć; informowano także o rodzinie założonej przez siebie (dane typu: rok wstąpienia w związek małżeński, imię i nazwisko małżonka, wykształcenie i wspólne dzieci - płeć, imiona, wiek). Sporadycznie wspominano o rozwodzie lub ponownym małżeństwie; przemilczano natomiast brak związku albo śmierć najbliższych. Opis etapów edukacji następował w porządku chronologicznym, od poziomu podstawowego i średniego; zdarzało się, że autor tekstu zamieszczał informacje o próbach podjęcia nauki na studiach (nazwa uczelni, rok egzaminów), negatywnych skutkach takich prób i ich przyczynach (jak np. brak miejsc). Podawano daty roczne rozpoczęcia i zakończenia nauki w danej instytucji oraz informacje o mieście, w którym jest placówka. Aby osiągnąć cel: przekonać odbiorcę o swojej wartości i wyjątkowości, autorzy zawierali opinię na temat własny lub określonego zakresu swojego dorobku. Wyrażali ją wprost (za pomocą słów i zwrotów wartościujących) bądź pośrednio (przez wskazanie osiągnięć albo działań obiektywnie mało znaczących, ale świadczących o ambicji, np. bycie członkiem pocztu sztandarowego czy prowadzenie szkolnych akcji). O niepowodzeniach (zawodowych, w zakresie wykształcenia, w życiu osobistym) mówiono sporadycznie - to umniejsza

${ }_{28}$ B. Boniecka, J. Panasiuk, Życiorys na tle innych wypowiedzi biograficznych, [w:] W zwierciadle języka i kultury, red. J. Adamowski, S. Niebrzegowska, Lublin 1999, s. 152-169.

29 Ibidem, s. 155. Oczywiście, w zależności od tekstu, jedne kategorie mogą być zrealizowane obszerniej, inne - w zawężeniu. 
wartość nadawcy w oczach odbiorcy, a więc jest sprzeczne z celem tworze-

nia życiorysu. Wspominano za to o przynależności do różnorodnych organizacji (zawodowych, partyjnych, do klubów czy towarzystw), czasami także o hobby albo o zainteresowaniach. Formalne wskazanie planów na przyszłość stanowiło kompozycyjne zamknięcie tekstu ${ }^{30}$.

Język życiorysu to język urzędowy. Pojawiają się stałe sformułowania wprowadzające poszczególne części tekstu, np.: „Nazywam się...”, „Ja, [...], urodziłam się...", „Pochodzę z rodziny...”, „Naukę rozpoczęłam...”, „Naukę kontynuowałam w...”, „Moje zainteresowania...”, „Przynależę do...”, „Interesuję się...", "Chciałabym...".

Dokument pisano z zachowaniem chronologii i porządku przyczynowo-skutkowego; to tekst narracyjny, w pierwszej osobie liczby pojedynczej.

\section{Analizowane wywiady}

W instrukcji dotyczącej sporządzania relacji dla Ośrodka „Pamięć i Przyszłość" można przeczytać, że relacja to zarejestrowana rozmowa ze Świadkiem Historii. Jest nagrywana, transkrybowana i archiwizowana w Archiwum Historii Mówionej Ośrodka „Pamięć i Przyszłość” (dalej: AHM OPiP). Archiwum to zbiera relacje o charakterze biograficznym; mają one ściśle określoną strukturę: składają się z trzech części (dotyczy to znacznej części, ale nie wszystkich nagrań, ponieważ instrukcja wprowadzona została w 2014 r., a AHM OPiP działa od 2007 r.) $)^{31}$. Pierwsza z nich konstruowana jest przez Świadka Historii na prośbę o opowiedzenie historii własnego życia. W jej trakcie prowadzący uważnie słucha. Druga część, to reakcja eksploratora na wysłuchaną historię: dopytanie o urwane wątki oraz ważne dla toku historii osoby, daty i miejsca. Ostatnia partia to pytania otwarte. Interlokutorami są zawsze: Świadek Historii (osoba prywatna) i przedstawiciel instytucji. Rozmowa taka jest nagrywana (dźwięk albo dźwięk i obraz). Celem jest badanie historii z perspektywy jednostki: daje to możliwość badania grup dotychczas nie badanych ${ }^{32}$ lub podejmowania tych wątków z przeszłości, które z różnych powodów (np. cenzura) nie mogły być zbadane.

$30 \quad$ Ibidem, s. 162-164.

31 Instrukcja sporządzania relacji do Archiwum Historii Mówionej Ośrodka „Pamięć i Przyszłość", http://www.pamieciprzyszlosc.pl/wp-content/uploads/2016/o2/Za-.1A-do-regulaminu_Instrukcja-sporz-dzania-relacji.pdf (dostęp: 15 VII 2016 r.).

32 Przykładem może być realizowany we współpracy z Ośrodkiem przez Fundację FONIS zapis historii mniejszości Głuchych Wrocławia w ramach projektu „Historia Migana". 
Pytanie o życiorys mówiony dotyczy pierwszej części wywiadu - swobodnej narracji. Dlatego o wyborze konkretnych relacji do analizy decydowało pierwsze pytanie zadawane przez prowadzącego wywiad: do analizy zakwalifikowałam wyłącznie takie transkrypcje wywiadów, które zaczynały się od prośby o opowiedzenie historii swojego życia. Nie zdecydowałam się na analizę takich wypowiedzi, które rozpoczynają się pytaniem badacza o doświadczenie wojny, dzieciństwo, udział w działaniach opozycji, opis przebiegu kariery zawodowej lub edukacji. Mimo obowiązującej instrukcji bogaty zbiór wywiadów zgromadzonych w Ośrodku (650 wywiadów) nie jest jednorodny - tylko część (53 wywiady) z nich rozpoczyna się taką prośbą.

Analiza zaczyna się po pytaniu zadanym przez prowadzącego wywiad; kończy się w chwili, gdy Świadek Historii w jasny sposób sygnalizuje koniec opowieści, np. kwituje ją stwierdzeniem podsumowującym życie („Ot, i tak minęło mi życie”) lub gdy eksplorator zaczyna zadawać pytania uszczegóławiające, tym samym przechodząc do drugiej części wywiadu. Długość takich wypowiedzi jest rozmaita: czasem to zaledwie kilka zdań3 ${ }^{33}$, czasem to barwna, kilkudziesięciominutowa opowieść ${ }^{34}$. Przykładem ultrakrótkiej, ograniczonej do jednego zdania, relacji, jest wypowiedź Stefanii Terleckiej: „No nie wiem, normalne życie. Pracowałam w mleczarni kupę lat, nie. No i tego" ${ }^{\text {"35 }}$.

33 Przykładem takiej krótkiej, zamkniętej wypowiedzi jest wypowiedź Olgi Lary, Archiwum Ośrodka „Pamięć i Przyszłość” (dalej: OPiP), sygn. AHM-16, z 29 III 2011 r., sporządził P. Sroka. Świadek Historii przedstawia się, informuje o związku małżeńskim i o odebranej edukacji. Wypowiedź składa się z pięciu zdań. Pozostałe informacje eksplorator pozyskuje, zadając konkretne pytania. Inną, krótką wypowiedzią jest wypowiedź Janiny Bilewicz-Berezowskiej (OPiP, sygn. AHM-38, z 12 VIII 2008 r., sporządził M. Kozłowski), która także obejmuje pięć zdań. Tym razem dowiadujemy się o miejscu pochodzenia, zawodzie ojca i o stanie majątkowym rodziny oraz o zmianie, która zaszła po wkroczeniu do rodzinnego Stryja armii sowieckiej. Ta wypowiedź kończy się, gdy pada pytanie eksploratora o rok wkroczenia Sowietów oraz prośba o zrelacjonowanie wydarzeń z czasów wojny.

34 Jako przykład długiej wypowiedzi można podać opowieść prof. Jana Miodka (OPiP, sygn. AHM-515, z 19 XI 2015 r., sporządziła K. Bock-Matuszyk) czy prof. Jana Wrabeca (OPiP, sygn. AHM-489, z 30 VI 2015 r., sporządził W. Bednarski).

35 OPiP, sygn. AHM-507, Relacja Stefanii Terleckiej z 25 VII 2015 r., sporządziła W. Rybarczyk. 
Uważne przyjrzenie się autobiograficznej części wypowiedzi Świadka Historii pozwala stwierdzić, że w pierwszej części wywiadu biograficzno-narracyjnego pojawia się kilka stałych elementów.

\section{Dane personalne}

Rozmówca podaje datę (24 osoby) - zwykle to rok i miesiąc (zaledwie 3 osoby podały pełną datę urodzenia) i miejsce urodzenia (31 osób). W większości wypadków zdanie przyjmuje brzmienie jak w poniższych przykładach:

Urodziłem się tutaj w Szklarskiej Porębie w październiku 1949 r. ${ }^{36}$

No, to moje życie rozpoczęło się [...] w kwietniu 1957 r. [... $]^{37}$.

Urodziłam się w Poznaniu ponad 8o lat temu ${ }^{38}$.

Wśród analizowanych wywiadów pojawiło się też ciekawe rozpoczęcie - bezpośrednie wprowadzenie do opowieści o kolejnym etapie życia (odebranym wykształceniu): „Jestem z tak zwanego złotego rocznika 1951. Dlaczego złoty? Dlatego, że podstawówka trwała tylko siedem lat" ${ }^{\text {39 }}$. Zdarza się również, że rozmówcy mówią o własnych dziejach odnosząc się do makrohistorii: „Uważam, że historia XX wieku głównie zaczęła się po I wojnie światowej. Ja byłem poczęty jeszcze w trakcie jej trwania" ${ }^{40}$.

Imię i nazwisko podawane jest przez rozmówców rzadziej (zaledwie 10 osób; dodatkowo 5 kobiet podało nazwisko rodowe, np. „Nazywam się Olga Kruczek. Po mężu Lara, z domu Kruczek"41), zwykle bowiem prowadzący wywiad zapowiada, z kim prowadzona będzie rozmowa.

36 OPiP, sygn. AHM-86, Relacja Zbigniewa Bogaczyka z 2 IX 2011 r., sporządził P. Sro$\mathrm{ka}$.

37 OPiP, sygn. AHM-566, Relacja Bolesława Ziobrowskiego z 5 VII 2015 r., sporządziła K. Bock-Matuszyk.

38 OPiP, sygn. AHM-517, Relacja Elżbiety Dobiejewskiej z 8 VII 2015 r., sporządziła K. Bock-Matuszyk.

39 OPiP, sygn. AHM-458, Relacja Marka Pospiesznego z 4 VIII 2014 r., sporządził K. Wasilewski.

40 OPiP, sygn. AHM-546, Relacja Bolesława Gleichgewichta z 13 II i 13 III 2014 r., sporządzili K. Bock i A. Jerie.

${ }_{41}$ Relacja O. Lary. 
We wstępach do narracji znajdujemy też informacje o pochodzeniu społecznym: rodzinie (w tym sporadycznie: imiona i nazwiska rodziców), przynależności zawodowej rodziców czy środowisku wychowania - ten wątek podejmowany jest szczególnie często w przypadku osób mieszkających na emigracji (warto zauważyć, że osoby przebywające w młodości na emigracji najszerzej opisują swoje rodziny i ich dzieje, skupiają się często na niej bardziej niż na swojej własnej historii). Mówi o tym większość: w analizowanym zbiorze ten wątek podjęło aż 38 osób. Opowieści te przybliżają rodzinną historię, czasem skomplikowaną:

Urodziłem się w robotniczej rodzinie, przez pierwsze 5 lat [...] mieszkałem z babcią i z dziadkiem, którzy przyjechali ze Kresów Wschodnich, ze Stanisławowa, a po 5 latach wyprowadziliśmy się z mamą i z ojcem [...] na [...] swoje, później urodziło mi się jeszcze troje rodzeństwa ${ }^{42}$.

W roku 1936 zmarł ojciec, w kwietniu. Został pochowany na cmentarzu Rossa w Wilnie, tam gdzie jest serce Piłsudskiego, jego matki cmentarz. W [19]36, w [19]37 r. zmarła mama i nas sześcioro rodzeństwa zabrano do domu dziecka ${ }^{43}$.

Rozmówcy dzielą się także refleksją o tym, jak ważny wpływ na to, kim jesteśmy, może wywierać świadomość tego, kim byli przodkowie:

Moimi rodzicami byli Wielkopolanie, dziadkami również. Można więc powiedzieć że w jakimś sensie do pracy organicznej przyzwyczajona byłam, bo jak to się mówi wyssałam to z mlekiem matki. Może dlatego moje życie bez jakiegoś specjalnego zadęcia tak się potoczyło, że byłam zawsze od najmłodszych lat zaangażowana w jakąś społeczną działalność ${ }^{44}$.

Wstępy różnią się pod względem kolejności i ilości podanych informacji. Ktoś zaczyna od przedstawienia się, ktoś inny od podania miejsca i daty urodzenia, a pomija informację o tym, kim jest. Opis rodziny może być lakoniczny, lub, jak w wypadku opowieści Bolesława Gleichgewichta,

42 Relacja B. Ziobrowskiego.

43 OPiP, sygn. AHM-534, Relacja Aleksandra Dowgiałło-Wierbila z 9 VII 2015 r., sporządziła W. Rybarczyk.

${ }_{44}$ Relacja E. Dobiejewskiej. 
bardzo rozbudowany, ze szczegółowymi informacjami na temat wykształcenia rodziców i języków, które znali i którymi posługiwali się w domu rodzinnym (w tej wypowiedzi opowieść o rodzinie przeplata się z opowieścią dotyczącą wykształcenia). W wielu wypadkach jednak zakres informacji jest podobny. Podają te same dane, które zawiera pierwsza część życiorysu pisanego. Można więc wysnuć tezę, że Świadkowie Historii intuicyjnie wiedzą, że te informacje powinni podać, przedstawiając historię swojego życia - tak, jakby nieświadomie realizowali jakiś wzorzec gatunkowy.

\section{Opis etapów edukacji}

Świadkowie Historii mówią o szkołach, do których uczęszczali - wątek ten podjęło 36 osób. Niektórzy przedstawiają spójny i całościowy opis swojej edukacji, bez względu na to, ile etapów ta edukacja obejmowała. Dzieje się tak w wypowiedzi Olgi Lary czy Franciszka Falewicza:

Podstawówkę ukończyłam w Futomie, ale to była szkoła sześcioklasowa. Następnie w Błażowej skończyłam klasę siódmą i trzyletnią szkołę handlową ${ }^{45}$.

Ja skończyłem tutaj podstawówkę. Później w Słupsku szkołę średnią. W Szczecinie studia $^{46}$.

Zbigniew Żbikowski także podaje dość spójną opowieść o swojej edukacji, jednak u niego pojawiają się fragmenty uzasadniające podjęcie kolejnego etapu edukacji (studium ekonomiczne) w związku z rozpoczęciem pracy:

W Zwierzynie rozpocząłem naukę w szkole podstawowej w 1959 r. [...] Później rozpocząłem naukę w liceum ogólnokształcącym w Strzelcach Krajeńskich. [...] po ukończeniu liceum podjąłem pracę już w Gorzowie, troszeczkę się związałem [...] ze studium ekonomicznym, które skończyłem w 1973 r. jako ekonomista z zakresu statystyki $[\ldots]^{47}$.

45 Relacja O. Lary.

46 OPiP, sygn. AHM-601, Relacja Franciszka Falewicza z 10 IX 2016 r., sporządziła A. Karmelita.

47 OPiP, sygn. AHM-453, Relacja Zbigniewa Żbikowskiego z 15 XI 2014 r., sporządził K. Wasilewski. 
Kolejna wypowiedź - poniżej - to skrót myślowy: mówiący informuje, że ukończył drugi etap edukacji, po czym reflektuje się i uzupełnia, że i pierwszy, i drugi. Takie zachowania językowe są typowe dla języka mówionego:

Ja w Giżycku skończyłem liceum pedagogiczne - to znaczy szkołę podstawową i liceum pedagogiczne. I potem poszedłem na studia na pedagogikę do Torunia. Ale te studia były dosyć nudne i zaproponowano $\mathrm{mi}$ - ponieważ interesowałem się tak zwaną, wtedy się mówiło, pedagogiką specjalną - zaproponowano mi pracę w Szklarskiej Porębie ${ }^{48}$.

Wśród opowieści o szkole można wyróżnić te, które także opisują całą ścieżkę edukacji, ale są przeplatane historią związaną z pierwszymi podejmowanymi pracami, licznymi komentarzami o sytuacji społecznej czy politycznej (jak w opowieści Gleichgewichta czy Jana Miodka) albo przedstawiają zmagania szkolne autora - problemy z językiem (Bonisław Prymus), konieczność zakończenia edukacji w związku z egzaminem w innej miejscowości (Maria Dura) czy niezrealizowanie marzeń z powodu braku miejsca w internacie (Edward Korban). Niektórzy dzielą się anegdotami z czasów szkolnych (Marek Czapliński). W opowieściach osób, które doświadczyły wojny we wczesnym dzieciństwie na ogół najpierw pojawia się historia wojny, a potem informacje o nauce: narracja jest chronologiczna.

W [19]37 r. [...], w czerwcu, ja ukończyłem gimnazjum i podałem [podanie] do, na studia, [...] na Uniwersytet Warszawski. Miałem... baliśmy się, czy będę przyjęty czy nie, to już był okres bardzo przykry w historii Polski. Polska była, nie była krajem totalitarnym, muszę powiedzieć, ale była krajem autorytatywnym/autorytarnym o $!^{49}$

No to ja nic nie rozumiałam. Mnie wszystkie dzieci się pytały, jak to się nazywa po niemiecku, jak to, a ja nie wiedziałam [...] co, jak odpowiadać, nie. No ale nie powiem, bo nie było źle. Także z elementarza się uczyłam i przy mnie i mama polskiego. I tak ${ }^{50}$.

${ }_{48}$ OPiP, sygn. AHM-94, Relacja Mariana Sajnoga z 12 VII 2011 r., sporządził P. Sroka.

49 Relacja B. Gleichgewichta.

5o OPiP, sygn. AHM-535, Relacja Bronisława Prymusa z 1 VIII 2015 r., sporządziła W. Rybarczyk. 
To mam jako zaświadczenie, ale nie mam ukończenia tych 7 klas, bo mieli my jechać do Lubasza, na egzaminy. Nikt nie chciał jechać. Ani tu Walerek Szweda, ani Sikora i tu wszyscy, Kordzina. Nikt nie chciał jechać ${ }^{51}$.

Do szkoły zaniesiono mnie w maju i pierwszą klasę ukończyłem już w czerwcu [...] skończyłem cztery klasy szkoły podstawowej. I następnie ukończyłem siedmioklasową szkołę [...]. I moim marzeniem [...] było [...], by być leśnikiem. Po ukończeniu szkoły podstawowej udałem się do miejscowości Ojców, tam zdałem egzamin do liceum leśnego [...]. Ale jak po zdaniu egzaminu [...] dowiedziałem się, że w tych, szkoła nie ma internatu. [...] Brat [...] powiedział, nie martw się, jeżeli cokolwiek potrafisz, to jest jeszcze możliwość zdawania egzaminu [...] taki egzamin będzie w liceum pedagogicznym w Myśliborzu. I przywiózł mnie do siebie, do Myśliborza [...] Zatem ja uzupełniałem wykształcenie. I najpierw ukończyłem studium nauczycielskie [...] w Szczecinie ${ }^{52}$.

Nie było ustępu na miejscu, trzeba było wychodzić na [dwór], do osobnego budyneczku, gdzie, który przypominał dzisiejsze, no, nie wiem co, ale w każdym razie pamiętam takie czasami były ustępy także na dworcach - dziura, prawda i tak dalej ${ }^{53}$.

W kontraście do tych długich i wielowątkowych historii pojawia się wypowiedź Lili Grabowskiej, która poświęca na opowieść o edukacji tylko jedno zdanie:

Ja mając 10 lat już z mamą pracowałam przy tym, no i chodziłam do szkoły ${ }^{54}$.

51 OPiP, sygn. AHM-506, Relacja Marii Dury z 6 VII 2015 r., sporządziła W. Rybarczyk.

52 OPiP, sygn. AHM-459, Relacja Edwarda Korbana z 6 X 2015 r., sporządził K. Wasilewski. W wypowiedzi tego Świadka Historii usunięte zostały komentarze, które powodują wydłużenie opowieści: w tym wypadku (gdy zależy mi na pokazaniu samych zdarzeń) zaburzają klarowność chronologii, typu: „więc była to edukacja bardzo, bardzo przyspieszona. Następnie w tej mojej miejscowości (skończyłem cztery klasy szkoły podstawowej)". W innych wypowiedziach nawiasem z wielokropkiem sygnalizuję usunięcie podobnych fragmentów bądź - częściej - powtórzeń czy przerw typowych dla języka mówionego, komentarze dotyczące sytuacji zewnętrznej (np. przerw na zastanowienie się zapisanych w transkrypcji jako „yyy”, komentarza [kaszel] itp.) - potrzebnych w zapisie wywiadu, ale utrudniających analizę treści wypowiedzi.

53 OPiP, AHM-545, Relacja Marka Czaplińskiego z 7 V 2014 r., sporządził M. Matuszyk.

54 OPiP, AHM-551, Relacja Lili Grabowskiej z 25 VIII 2009 r., sporządził A. Brzozowski. 
Są też takie wypowiedzi, w których lokutor opowieść o edukacji rozpoczyna od drugiego etapu edukacji, np. opisuje tylko studia albo szkołę średnią. Jest ich jednak stanowczo mniej (zaledwie pięć), i potwierdza to, że w większości wypadków Świadkowie Historii starają się zachować chronologię opisu:

W [19]46 r. rozpocząłem naukę w gimnazjum-liceum, bo tak to się wtedy nazywało. Gimnazjum-liceum w Pyskowicach, które ukończyłem w [19]51 r. Maturę zdatem w $[19] 51$ r. $[\ldots]^{55}$.

W badanym materiale znalazła się również wypowiedź na temat braku możliwości chodzenia do szkoły - mówi o tym jedna osoba: „Do szkoły nie chodziłam, tylko nigdzie nie, bo tak nie było wiadomo, że możliwości” wspomnienie o tym, że Irena Jessa nie uczyła się, może świadczyć o tym, że brak edukacji był dla niej ważny ${ }^{56}$. Inni, którzy nie odebrali edukacji, nie mówią o tym: nie należy tego traktować jako ukrywanie informacji. Im nauka odgrywa istotniejszą rolę dla Świadka Historii, im więcej pozytywnych wspomnień z nią się łączy, tym ten wątek jest dłuższy i barwniejszy.

Ten zakres tematyczny - edukacja - także pokrywa się z treścią życiorysu pisanego.

\section{Opis doświadczeń zawodowych}

Po przedstawieniu siebie i rodziny oraz opisie ścieżki edukacyjnej następuje - podobnie jak w życiorysie pisanym - przytoczenie historii zawodowej. Ogółem wątek pracy podejmuje 31 osób. Niekiedy nie udaje się Świadkowi Historii rozpocząć opowieści o pracy zawodowej, bo słuchający zadaje pytania uzupełniające (podobnie dzieje się w kilku wypadkach, gdy Świadek Historii opowiada o wojnie).

Nie ma jednego modelu mówienia o pracy zarobkowej. W przypadku profesorów uczelni wyższych często nauka i praca przenikają się (łatwo to zaobserwować w wypowiedzi prof. Jana Miodka, prof. Jana Wrabeca czy

55 OPiP, sygn. AHM-321, Relacja Jerzego Kowalskiego z 11 IV 2013 r., sporządziła E. Grodzka.

56 OPiP, sygn. AHM-502, Relacja Ireny Jessy z 26 VII 2015 r., sporządziła W. Rybarczyk. 
prof. Jerzego Kowalskiego). Najwięcej jest przypadków, gdy opowieść o pra-

cy to zamknięta część wypowiedzi; kilkoro Świadków Historii swoją pracę podsumowuje jednym zdaniem (Eugenia Jadanowska, Irena Jessa), czasem kilkoma (Franciszek Falewicz) lub kilkunastoma. Zdarza się, że ktoś mówi o pracy w kontekście współmałżonka (Maria Dura) - to kolejny przykład przenikania się wątków, przeplatania ich, nakładania na siebie:

W sklepie tu pracowałam, miałam $\operatorname{kiosek}^{57}$.

Pracowałam też tu na śluzie, 1o lat, potem zachorowałam, i tak się życie skończyło, że $[\ldots]$ już na emeryturę od razu poszłam, nie ${ }^{58}$.

Pracowałem w Słupsku jakiś czas, dość długo. Później przerzuciłem się. Wróciłem tu do Smołdzina do GS-u. W GS-ie pracowałem sporo lat. I znalazłem się na emeryturze, i tak siedzę do dziśn ${ }^{59}$.

[...] jako młodzież nigdzie nie pracowałam, bo [...] w gospodarstwie pracowałam. A jak się ożeniłam, to żyłam z mężem 9 lat, bo zginął mi z wypadku, [...] i miałam dwoje dzieci i rodziców bez renty, bez utrzymania, no i podjęłam pierwszą pracę w Mikołajewie w przedszkolu. Tam robiłam 9 miesięcy. No ale jakoś takoś nie wychodziło to, bo nie mogłam się z przedszkolanką zjednać, bo ja nie lubię kłamstwa. I wtedy poszłam do pracy do klubu. W klubie robiłam 9 lat. Z młodzieżą pracowałam, wesołe życie było, na zabawach śpiewałam, i tańce, zastępywałam na próbach za młodzież $\dot{z}^{60}$.

Fragment kolejnej relacji także pokazuje, jak toczyła się droga zawodowa rozmówczyni:

Dostałam przydział pracy, bo wtedy były przydziały pracy obowiązkowe, dostałam przydział pracy do „Miastoprojektu”. [...] W Szczecinie pracowałam 25 lat w „Miastoprojekcie” i [...] potem 11 lat w „Inwestprojekcie”, projektując budownictwo

57 OPiP, sygn. AHM-602, Relacja Eugenii Jadanowskiej z 18 IX 2016 r., sporządziła A. Karmelita.

${ }_{58}$ Relacja I. Jessy.

59 Relacja F. Falewicza.

60 Relacja M. Dury. 
mieszkaniowe, domy i osiedla w Szczecinie oraz domy wczasowe w pasie nadmorskim. Oraz robiliśmy z mężem konkursy architektoniczne. [...] Po przejściu na emeryturę prowadziłam działalność projektową przez wiele lat ${ }^{61}$.

Czasem o karierze zawodowej decydował nakaz pracy. W innym wypadku - jak wynika to z wypowiedzi Jana Jury - ważna była możliwość pracy blisko miejsca zamieszkania:

A jo jak tylko podrostołem, żeby się najeść, to do Krenza trochę, się nazywa sąsiod Krenz, nie. To on [...] miał już konika, on parcelę wziął na spłatę, tam już był chlyb, tam były krowy, tam już były świnie. No to on jak mnie zawołał do młócenia taką młocarką taką $[\ldots]^{62}$.

Zdarza się, że w wypowiedziach znaleźć można uzasadnienie pewnych faktów, jak w poniższych fragmentach. To istotna różnica w stosunku do dokumentu pisanego, w którym na tego typu informacje nie ma miejsca.

1 kwietnia już przestałem pracować, bo [...] rozwiązali fabrykę [...]. W każdym bądź razie [...] pracowałem tam od [19]62 do 1999, do końca marca. No i potem 1 kwietnia byłem już na [...] zasiłku [... $]^{63}$.

[...] dostałem [...] informację od mojego znajomego, że Ministerstwo [...] Rolnictwa robi nabór pracowników do pracy [...] w NRD. [...] Więc ja pojechałem do tej Warszawy do Ministerstwa Rolnictwa [...] człowiek mi się wprost spytał, czy chcę jechać, robić, bo tam jest fizyczna praca na [...] produkcji...? Ja mówię: „Oczywiście, że tak”, [...] po tygodniu czasu spakowałem się i pojechałem do miejscowości [...] Weimar, do firmy Landmaszyna [...] i rozpocząłem pracę, pracowałem jako frezer, przetaczacz na różnych tam maszynach [...] to trwało do, do roku [19]79, do maja, w maju [...] przyjechałem tutaj do kraju i dowiedziałem się, że jest nabór kierowców do PKS-u we Wrocławiu [...], tutaj pracowałem [...] do sierpnia [19]80 ${ }^{64}$.

61 OPiP, sygn. AHM-495, Relacja Renaty Fydy-Karwowskiej z 14 III 2015 r., sporządził G. Kaczorowski.

62 OPiP, sygn. AHM-503, Relacja Jana Jura z 6-7 VII 2015 r., sporządziła W. Rybarczyk.

63 Relacja J. Kowalskiego.

64 Relacja B. Ziobrowskiego. 
Profesor Miodek dzieli się informacją, że o karierze zadecydowało spotkanie z kimś i wspólne dzielenie pasji w okresie studenckim:

Natomiast dobry los sprawił, że gdzieś od drugiego roku studiów takim moim duchowym patronem na tychże studiach polonistycznych stał się nieżyjący już dr Franciszek Nieckula. I on [...] wciągnął mnie do studenckiego koła językoznawczego [...], dlatego po trzecim roku studiów, po którym wybiera się specjalność magisterską [...], ja nie poszedłem na żadne z seminariów historyczno-literackich, tylko wybrałem Stanisława Rosponda [...] i u Stanisława Rosponda zrobiłem magisterium poświęcone nazwom miejscowym kulturowym, prawda? Stanisław Rospond zaproponował mi asystenturę ${ }^{65}$.

Opis drogi zawodowej - jeżeli jest rozbudowany - następuje w porządku chronologicznym. W wypowiedzi Świadków Historii znajdujemy informacje o okolicznościach wyborów zawodowych i ich motywacjach.

Porażki, niespełnione plany, niezrealizowane marzenia, nagrody, wyróżnienia

W przeciwieństwie do narracji w życiorysie pisanym Świadkowie Historii dzielą się tym, co było w ich życiu dobre i tym, co było złe: mówią o swoich niespełnionych marzeniach oraz o planach, które z różnych powodów nie zostały zrealizowane; np. prof. Wrabec nie mógł spełnić marzeń z powodów organizacyjnych:

[...] chciałem [...] pójść na historię sztuki [...] Ale po prostu historii sztuki nie było. W szczególności we Wrocławiu. Tu, [19]53 r. [...], historia sztuki we Wrocławiu została zlikwidowana [...], więc właściwie zdecydowałem się na architekturę ${ }^{66}$.

Edward Korban ze względów osobistych odrzucił propozycję podjęcia studiów doktoranckich, a po latach żałował:

Zachęcano mnie i to jest jedyna, pierwsza sprawa, której bardzo żałuję [...] do rozpoczęcia natychmiast pracy... doktorskiej. No nie rozpocząłem tego ze względu na to, że w tym czasie oczywiście zajęty byłem wieloma problemami, a poza tym,

65 Relacja J. Miodka.

${ }_{66}$ Relacja J. Wrabeca. 
zawarłem związek małżeński, urodziły się moje dzieci [...]. Ale nie żałujmy tego, co z własnej przyczyny, mojej, nie zostało zrealizowane ${ }^{67}$.

Świadkowie mówią też o nagrodach czy wyróżnieniach, które mogły mieć wpływ na życie i karierę - tak było w przypadku Renaty Fydy-Karwowskiej - lub stanowiły podsumowanie życia (Miodek):

Na mistrzostwach akademickich w [19]54 w Poznaniu zdobyłam wicemistrzostwo Polski w skoku wzwyż [...] Za moje 4 tytuły wicemistrza [...] dostałam jakieś odznaczenie państwowe. To było normalne, że za wicemistrzostwo srebrny krzyż, a za pierwsze złoty krzyż $\dot{z}^{68}$.

[...] uhonorowano mnie przez ten czas trzema Wiktorami, Super Wiktorem, zaliczony zostałem w poczet pięćdziesięciu gwiazd telewizji polskiej na jej 50-lecie w roku 2002, w plebiscycie „Polityki”, to był rok 2000, no, w [rankingu] „Postacie telewizyjne" zająłem bardzo zaszczytne, czwarte miejsce $[. . .]^{69}$.

Podejmowanie takich wątków (szczególnie: pisanie o porażkach) to coś, co nie występowało w życiorysie pisanym (ewentualnie można było znaleźć informację o tym, dlaczego ktoś nie został przyjęty na studia). Być może, biorąc pod uwagę moment życia (wiele osób udzielających wywiadu to osoby starsze), wiązać to należy ze zmianą patrzenia na siebie i przewartościowaniem pewnych zdarzeń pod koniec życia. Wszak autorami życiorysów pisanych były zazwyczaj osoby młode, które życie dopiero zaczynały. Być może natomiast trzeba to wiązać z celami obu form wypowiedzi: życiorys pisany miał za zadanie zareklamować autora (pokazać od jak najlepszej strony), nie było w nim przestrzeni na pisanie o motywacjach; wypowiedź Świadków Historii ma pomóc poznać historię, więc informacje o tym, co się nie udało w przeszłości, są równie ważne, jak te o sukcesach.

67 Relacja E. Korbana.

${ }_{68}$ Relacja R. Fydy-Karwowskiej.

69 Relacja J. Miodka. 
lub grup formalnych, zainteresowania

Inny zakres tematyczny, który można zauważyć w wypowiedziach Świadków Historii, ale pokrywający się z tym, co można znaleźć w życiorysie pisanym, to informacje o przynależności do różnego rodzaju grup: formalnych i nieformalnych oraz o zainteresowaniach. Wątki te pojawiają się w toku opowieści w dwunastu wypowiedziach: zwykle przeplatają się z częścią dotyczącą edukacji (w szkole średniej, gimnazjum lub na studiach) - to różnica w stosunku do dokumentu pisanego, ponieważ w nim była wyznaczona część, w której informacje te mogły się znaleźć ${ }^{70}$. Opowieść o grupach czy zrzeszeniach pojawia się w tych dłuższych wypowiedziach.

Profesorowie wspominają aktywność w kołach naukowych. Mówi o tym m.in. prof. Miodek, opowiadając, jak członkostwo w kole naukowym zaważyło na jego późniejszej karierze; wspomina także prof. Gleichgewicht (aktywność w kole naukowym w gimnazjum, przed podjęciem studiów wyższych):

I on [...] miał ze mną zajęcia, wciągnął mnie do studenckiego koła językoznawczego, zacząłem przygotowywać pierwsze referaty, wyjeżdżać z nimi na zjazdy studenckich kół naukowych językoznawczych [... $]^{71}$.

[...] ja się zająłem chemią i byłem przewodniczącym kółka chemicznego. I potem nastąpiła moja wielka miłość, to była fizyka ${ }^{72}$.

Informacje o przynależności do organizacji znaleźć można w wypowiedzi byłego działacza organizacji młodzieżowych i partii politycznej oraz Polskiego Związku Piłki Nożnej, Marka Pospiesznego, a także w słowach Kazimierza Suproniuka, który przybliża szczegóły swojej przynależności do PSL:

Byłem działaczem Związku Młodzieży Socjalistycznej. Od 1963 r. [...] byłem wiceprzewodniczącym Zarządu Powiatowego ZMS w Międzychodzie. Byłem delegatem na zjazd ZMS w Poznaniu. Byłem również na trzecim zjeździe krajowym

\footnotetext{
$70 \quad$ B. Boniecka, J. Panasiuk, Życiorys..., s. 158.

71 Relacja J. Miodka.

72 Relacja B. Gleichgewichta.
} 
ZMS w Warszawie. Działalność w ruchu młodzieżowym łączyłem z działalnością sportową, bo od 1964 r. byłem piłkarzem Warty Międzychód. Byłem trampkarzem, juniorem, seniorem ${ }^{73}$.

Ponieważ żona pracowała w "Stilonie” na trzy zmiany, a moja praca wiązała się i z pracą do południa i po południu, bo były zebrania na wsiach... i w związku z tym nie pozwalało mi, bo nie miałby kto się opiekować dziećmi i... w związku z tym zrezygnowałem z pracy etatowej, ale ciągle byłem aktywnym członkiem PSL-u $[\ldots]^{74}$.

Elżbieta Dobiejewska i ks. Józef Puciłowski wspominają przynależność do organizacji religijnych:

Spotkałam się z ludźmi z Klubu Inteligencji Katolickiej, choć kontakt nieformalny miałam z nimi od [19]56 r. Bo mój ówczesny narzeczony, a potem mąż, Zbigniew Dobiejewski, był kuzynem pierwszego prezesa Klubu Inteligencji Katolickiej ${ }^{75}$.

Ja byłem związany prawie cały czas z Centralnym Duszpasterstwem Akademickim księdza Aleksandra Zienkiewicza ${ }^{76}$.

Kluby sportowe, organizacje religijne czy młodzieżowe, zainteresowania - wszystko to jest poruszane przez Świadków Historii. W życiorysach pisanych informacja o przynależności do zrzeszeń czy zainteresowaniach wiąże się z chęcią pokazania odbiorcy doświadczenia lub (pośrednio, przez pełnione funkcje) pokazania swoich kompetencji w określonym zakresie ${ }^{77}$. Przyczyna mówienia na ten temat w świadectwach historycznych - w życiorysach mówionych - może być związana z uświadamianiem sobie roli różnego rodzaju zrzeszeń czy zainteresowań w rozwoju i dostrzegania ich wpływu na późniejsze ich życie.

73 Relacja M. Pospiesznego.

${ }_{74}$ OPiP, sygn. AHM-446, Relacja Kazimierza Suproniuka z 10 III 2014 r., sporządził K. Wasilewski.

75 Relacja E. Dobiejewskiej.

76 OPiP, sygn. AHM-516, Relacja Józefa Puciłowskiego OP z 3 VI 2015 r., sporządził M. Szajda.

77 B. Boniecka, J. Panasiuk, Życiorys..., s. 163-165. 
Podobnie jak w życiorysie pisanym, również i w wypowiedziach autobiograficznych mówi się o własnej rodzinie. I, także jak w wypadku mówienia o edukacji czy doświadczeniu zawodowym, może to być jedno zdanie informujące o związku małżeńskim (Irena Jessa, Eugenia Jadanowska) lub może to być rozbudowana historia (prof. Kowalski, prof. Miodek):

No i do 20, 23 lata, w [19]53 r. wyszłam za mąż ${ }^{78}$.

Znowu [...] w [19]65 r. za mąż wyszła[m], zapoznałam się, no i miałam trójkę dzieci. Dwie córki i syna ${ }^{79}$.

W międzyczasie [...] rodzina nam się powiększyła. [...] Starszy syn się ożenił [...] mamy wnuki [...] troje dziewcząt. [...] Najstarsza studiuje [...] we Wrocławiu na prawie, tak. Na piątym roku jest [...]. Średnia Ewa jest na anglistyce [...] Kuba [...]. To jest nasz rodzynek, oczko w głowie. Skończył maturę. [...] Bo on na stomatologię chciał się dostać, nie dostał się $e^{80}$.

Ożeniłem się tuż po studiach z koleżanką z roku, Teresą Taczanowską, ale matrymonialnie [...] połączyło nas [...] wspólne śpiewanie. [...]. Przeżyłem z moją żoną 47 lat od [19]68 r. W roku 1976 urodził nam się syn Marcin [...]. On też tuż po studiach w roku 2000 się ożenił, no i z tego związku [...] narodziło im się [...] dwóch synów, więc mogę powiedzieć, że mam dwóch wnuków: 9-letniego Wiktora i 3-letniego Huberta ${ }^{81}$.

Czasem natomiast to informacja podana jakby przy okazji mówienia, np. o pracy zawodowej:

Miałam dwoje małych dzieci [...]. Ale musiałam z nimi chodzić w pole, musiałam snopki stawiać tak jak żony innych pracowników, zabierałam dzieci, braliśmy na wóz, potem, jak w czasie deszczu, dzieci siedziały pod wozem pochowane, a myśmy układały snopki ${ }^{82}$.

78 Relacja I. Jessy.

79 Relacja E. Jadanowskiej.

so Relacja J. Kowalskiego.

81 Relacja J. Miodka.

82 OPiP, sygn. AHM-532, Relacja Ludmiły Muńko z 31 VII 2015 r., sporządziła W. Rybarczyk. 
Wątek ten pojawia się albo na końcu wypowiedzi autobiograficznej, albo chronologicznie, w wyniku opowieści, u trzynastu osób. Choć więc nie ma jednego schematu, jak mówić o rodzinie, to jest to kolejny obszar, który pokrywa się z tym, co można znaleźć w życiorysie pisanym.

\section{Podsumowanie życiorysu}

Podsumowanie życiorysu to czasem jedno, czasem kilka zdań, w których wyrażona jest głębsza refleksja. Często Świadek Historii na głos zadaje sam sobie retoryczne pytanie o to, co mógłby powiedzieć poza tym, co już opowiedział. Zdarza się, iż podsumowuje swoje życie krótkim stwierdzeniem, np.:

I zostałem ja, najstarszy, jeszcze z tego rodu, żyjący, powiedzmy, który pamięta te czasy przyjazdu z Poznania do Trzcianki, tutaj powiedzmy funkcjonowania do dnia dzisiejszego, tak to wyglądało w skrócie ${ }^{83}$.

Albo:

Tak, pani doktor, w skrócie się przedstawia historia mojego życia, z uwzględnieniem [...] pracy zawodowej, tej otoczki medialnej, [...] o życiu rodzinnym swoim też pani wszystko powiedziałem: żona, syn, wnuki... ${ }^{84}$.

Tu nie ma reguły - najczęściej po prostu prowadzący wywiad dopytuje o coś i w naturalny dla konwersacji sposób część autobiograficzna się kończy.

\section{Czy istnieje życiorys mówiony?}

Jeżeli przyjrzeć się cechom życiorysu opisanym przez Boniecką i Panasiuk, można stwierdzić, że dla obu typów wypowiedzi (wypowiedź Świadka Historii i życiorys) będą wspólne: część dotycząca danych personalnych, opis przebiegu edukacji szkolnej, etapy pracy zawodowej, informacje o rodzinie, przynależności do organizacji społecznych i zainteresowaniach. Nie ma w wypowiedzi mówionej: informacji o kwalifikacjach ani tego, co zostało określone jako perspektywy na przyszłość (wiąże się z wiekiem i większą potrzebą podsumowania swojego życia, niż wyrażaniem siebie i próbą

${ }_{83}$ OPiP, sygn. AHM-508, Relacja Jana Dąbrowskiego z 3 VI 2015 r., sporządziła W. Rybarczyk.

${ }_{84}$ Relacja J. Miodka. 
przedstawienia siebie w jak najlepszym świetle, pokazania, że jest się kompetentnym do pewnego rodzaju prac). Nową kategorią w tym zbiorze jest mówienie o porażkach, niespełnionych planach, niezrealizowanych marzeniach, nagrodach i wyróżnieniach; podejmuje się także kwestie okoliczności zaistnienia kluczowych wydarzeń w życiu oraz motywacje podejmowanych wyborów (określonej szkoły, kierunku studiów, pracy).

Zdaniem Bachtina gatunek można opisać, charakteryzując jego cel i treść, kompozycję i styl ${ }^{85}$. Muszą one być w miarę stałe w każdej realizacji gatunkowej. Jak wygląda to w odniesieniu do badanej wypowiedzi autobiograficznej?

a. Celem wypowiedzi Świadków Historii jest przedstawienie swojego życia, cel ten narzuca sytuacja: rozmowa nie odbywa się w warunkach codziennych, osoba mówiąca zostaje Świadkiem Historii i o swoim życiu opowiada wobec przedstawiciela instytucji, jej opowiadanie ma pomóc w badaniu historii. Cel jest za każdym razem ten sam. W odróżnieniu od życiorysu pisanego, nie jest warunkiem koniecznym zrobienie dobrego wrażenia (tym można tłumaczyć fakt, że rozmówcy mówią o błędach, niespełnionych marzeniach itp.) - życiorys pisany powstawał z myślą o przyszłości (przedkładano go w miejscach, które mogły mieć wpływ na przyszłość autora), monolog Świadka Historii ma pomóc badać historię.

b. Treść relacji stanowią tematy podobne do tych poruszanych w życiorysie pisanym: pochodzenie, edukacja, przebieg ścieżki kariery, własna rodzina, nagrody czy wyróżnienia, ewentualnie opowieść o niezrealizowanych planach lub marzeniach. Nikt nie określa przed wywiadem, o czym powinno się mówić w części autobiograficznej wywiadu, nie ma instrukcji, która mówi, że Świadek Historii powinien poruszyć kwestie swojej rodziny, ma powiedzieć, gdzie się urodził czy gdzie się uczył. Świadkowie decydują, o czym mówią w części biograficznej, tak, jakby intuicyjnie wiedzieli, jakie informacje powinny w tej opowieści się znaleźć.

Wybrane przeze mnie wypowiedzi realizują jedną z podstawowych biograficznych struktur procesowych opisanych przez Fritza Schützego - instytucjonalne wzorce oczekiwań (tu ten wzorzec realizuje się jako życiorys mówiony). Polega on na podążaniu przez mówcę instytucjonalnie ukształtowanymi i normatywnie zdefiniowanymi przebiegami życia, takimi jak ścieżki

85 M. Bachtin, op. cit., s. 350. 
94 kariery w organizacjach czy związanymi z rodziną cyklami życia ${ }^{86}$. Struktury te to najważniejsze zasady porządkujące historię życia, rozumianą jako narracyjna całość i wyobrażaną jako uporządkowana sekwencja osobistych doświadczeń ${ }^{87}$. Ten instytucjonalny wzorzec oczekiwań wyrażony został wprost przez Michała Szydywara, który na prośbę o opowiedzenie historii swojego życia zapytał: „Co to, życiorys jakiś taki?”88.

c. Styl. Tym, co najbardziej różnicuje wypowiedzi, jest styl. Wypowiedzi Świadków Historii realizują cechy języka mówionego, jednak styl w dużym stopniu zależy od kompetencji językowych mówiącego.

W warstwie językowej zauważa się także: stosowanie typowych dla języka potocznego: skrótów przy podawaniu dat („7 czerwca czterdziestego szóstego roku”, „Zaraz po wojnie, w czterdziestym siódmym roku wyjechaliśmy z rodzicami do Giżycka z tej twierdzy"89), przerw i zdań eliptycznych oraz niepełnych. Notuje się także błędy, takie jak: *w każdym bądź razie (poprawnie: w każdym razie), "tam dostała tą chałupę (poprawnie: tę chałupę), kobieta o sobie: *ożeniłam się (zamiast: wyszłam za mąż), które również można przypisać językowi potocznemu.

W zależności od indywidualnej wymowy notuje się regionalizmy w wymowie: zastępywałam (zastępowałam), tam już byt chlyb (tam już był chleb), miałam kiosek (miałam kiosk).

${ }_{86}$ F. Schütze, Analiza biograficzna ugruntowana empirycznie $w$ autobiograficznym wywiadzie narracyjnym. Jak analizować autobiograficzne wywiady narracyjne, [w:] Metoda biograficzna w socjologii, red. K. Kaźmierska, Kraków 2012, s. 157.

${ }^{87}$ Ibidem, s. 157. Wśród najważniejszych z nich, poza instytucjonalnymi wzorcami oczekiwań, wymienia się jeszcze: biograficzne schematy działania (w nich człowiek próbuje mieć wpływ na przebieg swojego życia), trajektorie cierpienia (kiedy jednostka nie jest w stanie aktywnie kształtować swojego życia i tylko reaguje na przytłaczające zdarzenia zewnętrzne, takie jak wojna). Ostatnią ze struktur wymienianych przez Schützego jest metamorfoza - twórcza przemiana tożsamości biograficznej, dzięki której w biografii człowieka inicjowana jest nowa, istotna wewnętrzna linia rozwoju (początkowo może być ona oceniana całkiem polarnie, jako cudowna albo irytująca). Wszystkie te biograficzne struktury procesowe zazwyczaj następują po sobie, dominując w poszczególnych fragmentach biografii i tworząc splot sekwencyjny, ibidem, s. 158 .

${ }_{8}$ OPiP, sygn. AHM-525, Relacja Michała Szydywara z 8 IV 2015 r., sporządził T. Kosiek.

s9 Relacja M. Sajnoga. 
Zauważa się występowanie zaimków wskazujących i powtórzeń w wielu wypowiedziach (np. „no to musiałem [...] się wszystkim zajmować, przypilnować, zrobić i tak, i tak” ", „No i [...] tego" ${ }^{91}$, „[...] wyjechaliśmy z rodzicami do Giżycka z tej twierdzy. Całą wojnę żeśmy przeżyli tam pod tą twierdzą, a zaraz po wojnie wyjechaliśmy do Giżycka" ${ }^{92}$ ) często spotykanych w języ$\mathrm{ku}$ potocznym. Innym zjawiskiem z zakresu składni są zdania zamknięte partykułą „nie”, np. „Pracowałam też tu na śluzie, 10 lat, potem zachorowałam, i tak się życie skończyło, że już na emeryturę od razu poszłam, nie"; „A jo jak tylko podrostołem, żeby się najeść, to do Krenza trochę, się nazywa sąsiod Krenz, nie".

Są też błędy składniowe (np. „Uczestniczyłem do szkoły podstawowej”, „Później do szkoły już poszłam od 6 lat”) i zdania niezrozumiałe dla czytelnika transkrypcji ${ }^{93}:$ „Więc matka dostała za pozostawione mienie, tam za takie jedne, bo mieliśmy sześć kartek tak zwanych ewakuacyjnych, i facet nas przywiózł taką furą na koniu, z pięciorgiem dzieci, bo nas z domu jest trójka i dwójka była przybranych, gdzie zamordowali mojej matki brata" przytoczone zdanie nie jest spójne logicznie, występuje w nim kilka podmiotów: matka, my, facet, oni; podjętych zostało kilka wątków. To także cecha obserwowana w języku potocznym.

Są sytuacje, w których słuchacz może czuć się „wrzucony” w opowiadanie: wątek podejmowany przez Świadka Historii pojawia się nagle i dopiero późniejsze fragmenty wypowiedzi pozwalają zrozumieć myśl i poznać całe wydarzenie: „Moja mama, emigrując z Polesia, z Horodyszcza koło Pińska... zatrzymała się... jako już wdowa we Włodawie. Tam była krótko gospodynią u księży. I poznała... swego drugiego męża Suproniuka, bo wcześniej nazywała się... z domu była Sawoch, wyszła za Milkowicza i..." 94 .

Najczęściej rozmówcy wypowiadają się w pierwszej osobie (liczby pojedynczej, jeśli mówią o czymś dotyczącym ich bezpośrednio, np. „byłem działaczem młodzieżowym" ${ }^{\prime 5}$, lub liczby mnogiej - jeśli przykładowo

\footnotetext{
9 Relacja J. Dąbrowskiego.

91 Relacja S. Terleckiej.

92 Relacja M. Sajnoga.

${ }_{93}$ Zdania te, czy nawet całe fragmenty wypowiedzi, bywają niejasne dla czytelnika transkrypcji, mimo to badacz obecny na spotkaniu ze Świadkiem Historii nie ma zazwyczaj problemu z ich zrozumieniem.

${ }_{9}$ Relacja K. Suproniuka.

95 Ibidem.
} 
opowiadają o rodzinie, której byli członkami, np. „Ojciec był więźniem obozów w Compiègne, w Dachau, wreszcie w Mauthausen, gdzie zadręczony zmarł w ostatnią niedzielę kwietnia 1934 r., albo w pierwszą niedzielę maja, nie wiedzieliśmy" ${ }^{\text {"96}}$ ). Zdarza się stosowanie form bezosobowych, np. „prowadzono względem mojej osoby” "97 „I w Krzyżu zgrupowano ogromną ilość rodzin niemieckich i czekających na pociąg, który ich miał przewieźć za Odrę ${ }^{98}$. To związane jest z ekonomią językową (jeśli wcześniej określono wykonawcę czynności, forma bezosobowa pozwala szybko i precyzyjnie mówić o działaniu) lub wynika z niewiedzy (czynności wykonywał ktoś, ale nie wiadomo, kto). Trudno jednoznacznie stwierdzić, czy ich stosowanie to np. wpływ stylu urzędowego.

Profesorowie uczelni wyższych z większą łatwością posługują się językiem plastycznym, opisowym, sięgają po wyrażenia frazeologiczne i częściej mówią zdaniami podrzędnie złożonymi, nawet wielokrotnie. Osoby, które otrzymały niższe wykształcenie, koncentrują się na przedstawianiu faktów, raczej nie posługują się też tak barwnym językiem. Jednak w każdej wypowiedzi zdarzają się powtórzenia, zdania o nieprawidłowej konstrukcji gramatycznej i opisane wcześniej cechy typowe dla języka mówionego.

d. Kompozycja. Wypowiedzi mają różną długość - zależy ona często od sprawności językowej Świadka Historii. Każda z nich ma wyraźne sygnały początku i końca. Bez względu na długość zachowane są: ciąg przyczynowo-skutkowy oraz chronologia. Im dłuższa opowieść, tym więcej notuje się dygresji i dopowiedzeń (to jest znacząca różnica w stosunku do życiorysu pisanego, którego struktura jest bardzo sztywna, a i długość w miarę określona).

Zakres treści nie zawsze się pokrywa. Na pewno każda wypowiedź rozpoczyna się od przedstawienia się (przytaczane są informacje, takie jak: data urodzenia, imię i nazwisko, nazwisko rodowe, rodzina, miejsce urodzenia). Choć żaden $\mathrm{z}$ analizowanych przykładów nie zawiera wszystkich wymienionych treści, każdy rodzaj informacji można znaleźć w około 50\% wypowiedzi. Drugi element treściowy to edukacja i jej przebieg. Następnie Świadkowie Historii przedstawiają opis drogi zawodowej, podają informacje o przynależności do organizacji i zrzeszeń, zainteresowania i mówią o własnej rodzinie. Podobnie jak informacje z pierwszej części nie pojawiają się w każdej wypowiedzi,

96 Relacja R. Fydy-Karwowskiej.

97 Relacja B. Ziobrowskiego.

98 Relacja J. Dąbrowskiego. 
tak dzieje się z pozostałymi danymi: nie każdy życiorys mówiony je zawiera, pojawiają się w około połowie wywiadów: czasem ktoś skupia się na rodzinie i edukacji, a czasem ktoś opowiada o karierze i przynależności do zrzeszeń. Zdarza się, że ktoś podejmie wszystkie wątki, a całą opowieść okrasi sporą liczbą anegdot. Mimo to wymienione zakresy tematyczne powtarzają się w analizowanym materiale: szkielet konstrukcyjny jest powtarzalny. Na treść życiorysu mówionego wpływa z pewnością doświadczenie traumy (nie zawsze osoby, które doświadczyły wojny, są w stanie opowiedzieć o całym swoim życiu, zdarza się, że koncentrują się na tym doświadczeniu) lub wspomniana wcześniej kompetencja językowa - w takich sytuacjach daje się zauważyć życiorys mówiony skrócony do minimum: do pierwszej części zawierającej dane osobowe:

Dobrze. Tylko, wie pan, ja miałam wtedy, znaczy, ja... tych takich lat dawnych, dawnych takich bardzo, to nie pamiętam, bo jak wybuchła wojna, to ja miałam 7 lat. A jako dziecko, nie? jako dziecko mała byłam, no to, no to jak to na wsi ludzie normalnie żyły, jakoś tak. Jeden sąsiad, jeden z drugim, nie było żadnych takich zatargów, żeby jakieś takie były nieporozumienia. Jakoś ludzie żyli w zgodzie, pomagali sobie. I mnie najbardziej utkwił właśnie wrzesień, 1 wrzesień. Ja wtedy...99.

Proszę pana, no... no urodziłem się, proszę pana, 1932 r. w Helenkowie. To jest powiat Brzeżany, województwo Tarnopol. Ojciec [...]. Natomiast na Wschodzie, proszę pana, działała banda, proszę pana, ukraińska. Natomiast przed wojną żyli ludzie i aby tak jakoś spokojnie. Było, proszę pana, ich jakoś jedna trzecia w naszej miejscowości, w tym Helenkowie ${ }^{100}$.

Struktura życiorysu pisanego widoczna jest najmocniej w krótkich wypowiedziach, gdzie w kilku zdaniach lokutorzy próbują powiedzieć o sobie wszystko, czyli właśnie podają te informacje, które intuicyjnie odczuwają jako konieczne. W wypowiedziach dłuższych prosta struktura ulega skomplikowaniu, pojawiają się anegdotki czy komentarze polityczne, jednak po ich oddzieleniu także z łatwością można zrekonstruować szkielet życiorysu pisanego. Znaczącą różnicą w stosunku do życiorysu pisanego jest fakt, że na siatkę wydarzeń osobistych zwykle nakładają się wydarzenia globalne (przenikanie mikro- i makrohistorii).

99 OPiP, sygn. AHM-476, Relacja Irminy Wiczewskiej z 6 VI 2008 r., sporządził M. Kozlowski.

100 OPiP, sygn. AHM-475, Relacja Tadeusza Sochackiego z 18 VI 2008 r., sporządził M. Kozłowski. 
Podobieństwo jest wynikiem zawarcia w konkretnej wypowiedzi określonej liczby cech typowych dla wypowiedzi stanowiącej wzorzec (podobieństwo ilościowe polega na odniesieniu do struktury podstawowej, a jakościowe - na specyfice tych cech) ${ }^{101}$. Jeśli więc założyć, że początek jest ten sam i zakres tematyczny również ten sam (choć kolejność może być zmienna, wątki przenikają się), z całą pewnością można powiedzieć, że życiorys mówiony istnieje.

\section{Zakończenie}

Analiza pierwszych, biograficznych części relacji historii mówionej zgromadzonych w AHM OPiP pozwala zauważyć, że Świadkowie Historii stosują podobny schemat, kiedy (dla celów badania historii) opowiadają o swoim życiu. Ich opowieści, mimo że powstają niezależnie, mają podobną strukturę i zakres podejmowanych tematów; podobne są też do życiorysu pisanego, rozpowszechnionego w Polsce po II wojnie światowej. Schütze twierdzi, iż autobiograficznej opowieści nie powinno się traktować jako tekstu tworzonego przez mówiącego w sposób dowolny i elastyczny i mówi o poważnym zamiarze i naglącej potrzebie, która wymusza, co i jak opowiadać, mówiąc o wydarzeniach w historii życia, o ile nie została ona wcześniej przedstawiona czy zrytualizowana ${ }^{102}$. Można zatem przypuszczać, że życiorys pisany wpłynął na sposób konstruowania wypowiedzi ustnej na potrzeby instytucjonalne.

Potwierdzenia tej tezy można szukać w stwierdzeniu, że zauważalny jest wyraźny wpływ języka komunikatów urzędowych, publicystyki społecznej i tekstów popularnonaukowych na polszczyznę mówioną ${ }^{103}$, a w utrwalaniu i przekazywaniu wzorców gatunkowych istotną rolę odgrywa szkoła. Działania edukacyjne na różnych poziomach, od szkół podstawowych poczynając, zakładają opanowywanie umiejętności budowania różnogatunkowych tekstów, o ukształtowaniu wewnętrznym właściwym gatunkowi (list, recenzja, życiorys, wiersz itp. ${ }^{104}$. Większość uczestników wywiadów

101 S. Sawicki, Gatunek literacki: pojęcie klasyfikacyjne, typologiczne, politypiczne?, [w:] Problemy metodologiczne wspótczesnego literaturoznawstwa, red. H. Markiewicz, J. Sławiński, Kraków 1976; za: K. Wyrwas, Skarga jako gatunek mowy, Katowice 2002, S. 18 .

102 F. Schütze, op. cit., s. 162.

103 A. Wilkoń, Typologia odmian współczesnej polszczyzny, Katowice 20oo, s. 41.

104 J. Bartmiński, Tekst jako przedmiot tekstologii lingwistycznej, Lublin 1998, s. 54. 
poddanych analizie brała udział w procesie edukacji, prawdopodobnie więc wzorzec gatunkowy języka pisanego przeniknął do języka mówionego. W ten sposób, na potrzeby sytuacji, powstał nowy gatunek języka mówionego - życiorys mówiony ${ }^{105}$, który jest (paradoksalnie ${ }^{106}$ ) gatunkiem wtórnym do życiorysu pisanego.

105 Warto dodać, że prawdopodobnie opisywanym przeze mnie gatunkiem będą posługiwać się osoby urodzone w określonym czasie. Podstawowym powodem jest ograniczony czas istnienia życiorysu pisanego w rzeczywistości społecznej. W opowiadaniu o sobie życiorys mówiony stosować będą osoby, które miały możliwość poznać strukturę życiorysu w szkole lub w swojej praktyce zawodowej. Trudno powiedzieć, jakie będą zachowania językowe dzisiejszych 20- i 3o-latków, ponieważ mało kto jeszcze udzielił wywiadu - świadectwa historii mówionej. Trudno też powiedzieć, jak mówią o sobie dzisiejsi 40- i 5o-latkowie - choć zasoby Ośrodka „Pamięć i Przyszłość" obejmują wypowiedzi osób w tym wieku, wywiad rozpoczynany jest prośbą o opowiedzenie konkretnego wydarzenia historycznego.

106 Paradoks ten wynika $\mathrm{z}$ faktu, że gatunki pierwotne to na ogół gatunki mówione, wtórne - pisane. 


\section{Bibliografia}

Bachtin M., Problem gatunków mowy, [w:] idem, Estetyka twórczości stownej, Warszawa 1986, s. $348-402$

Bartmiński J., Tekst jako przedmiot tekstologii lingwistycznej, Lublin 1998

Belke H., Problemy typologii i klasyfikacji tekstów użytkowych, „Pamiętnik Literacki”, nr 70 (1979), z. 3, s. 323-346

Boniecka B., Panasiuk J., Życiorys na tle innych wypowiedzi biograficznych, [w:] W zwierciadle jezzkka $i$ kultury, red. J. Adamowski, S. Niebrzegowska, Lublin 1999, s. 152-169

Buttler D., Kurkowska H., Satkiewicz H., Kultura jezzka polskiego, t. 1, Warszawa 1971

Dobrzyńska T., Badanie struktury tekstu, [w:] Polska genologia lingwistyczna, red. D. Ostaszewska, R. Cudak, Warszawa 2008, s. 81-94

Loth R., Franciszka Fiszera anegdoty autobiograficzne, [w:] Żywiot słowa. Literatura i jej formy mówione, red. J. Maciejewski, Łódź 2007, s. 115-128

Maciejewski J., Literatura i jej formy mówione, [w:] Żywiot stowa. Literatura i jej formy mówione, red. J. Maciejewski, Łódź 2007, s. 9-26

Okopień-Sławińska A., Teoria wypowiedzi jako podstawa komunikacyjnej teorii dzieła literackiego, „Pamiętnik Literacki”, nr 79/1 (1988), s. 165-181

Ostaszewska D., Genologia lingwistyczna jako subdyscyplina współczesnego językoznawstwa, [w:] Polska genologia lingwistyczna, red. D. Ostaszewska, R. Cudak, Warszawa 20o8, s. 11-42

Rancew-Sikora D., Analiza konwersacyjna jako metoda badania rozmów codziennych, Warszawa 2007

Schütze F., Analiza biograficzna ugruntowana empirycznie $w$ autobiograficznym wywiadzie narracyjnym. Jak analizować autobiograficzne wywiady narracyjne, [w:] Metoda biograficzna w socjologii, red. K. Kaźmierska, Kraków 2012

Skwarczyńska S., Wstęp do nauki o literaturze, t. 3, Warszawa 1965

Stownik Języka Polskiego PWN on-line, http://sjp.pwn.pl/sjp/zyciorys;2548402.html

Wilkoń A., Gatunki mówione, Internetowa Konferencja Naukowa „Porozmawiajmy o rozmowie”, http://uranos.cto.us.edu.pl/ rozmowa/wilkon.htm

Wilkoń A., Typologia odmian wspótczesnej polszczyzny, Katowice 2000

Wyrwas K., Skarga jako gatunek mowy, Katowice 2002

Zaśko-Zielińska M., Przez okno świadomości. Gatunki mowy w świadomości użytkowników ję$z y k a$, Wrocław 2002 
The author of the article discusses the subject of a spoken biography. These considerations are based on recordings of the accounts of the witnesses to history, gathered in the Oral History Archive of the "Remembrance and Future" Center. The free narratives of the witnesses are analyzed using the structure of a written biography, the basic elements of which are identified using the statements of individual people. On this basis, the author concludes about the existence of a spoken biography as a specific way of telling about the course of one's own life, which the interlocutors unconsciously construct as a written equivalent. The background of the analyzes is a discussion of theoretical-literary studies on the genre as a text pattern and the characteristics of the basic differences between written and spoken language.

Key words: oral history, written biography, spoken biography, biographical narrative
Maria Rudnicka

Does spoken biography exist? On the penetration of written and spoken form a geneological test based on the analysis of autobiographical accounts 